\title{
A Promoter from Pea Gene DRR206 Is Suitable to Regulate an Elicitor-Coding Gene and Develop Disease Resistance
}

\author{
Jane Junghae Choi, Steven Joseph Klosterman, and Lee A. Hadwiger
}

Department of Plant Pathology, P.O. Box 6430, Washington State University, Pullman 99164.

Current address of J. J. Choi: U.S. Department of Agriculture-Agricultural Research Service, Foreign Disease-Weed Science Research Unit (FDWSR), 1301 Ditto Ave., Fort Detrick, MD 21702.

Current address of S. J. Klosterman: Plant Pathology, University of Georgia, Athens 30602.

Accepted for publication 26 January 2004.

\begin{abstract}
Choi, J. J., Klosterman, S. J., and Hadwiger, L. A. 2004. A promoter from pea gene DRR206 is suitable to regulate an elicitor-coding gene and develop disease resistance. Phytopathology 94:651-660.

Plant nonhost disease resistance is characterized by the induction of multiple defense genes. The pea DRR206 gene is induced following inoculation with pathogens and treatment with abiotic agents, and moderately induced by wounding. A deletion series of DRR206 promoter segments was fused with the $\beta$-glucuronidase (GUS) reporter gene and transiently transferred to tobacco, potato, and pea. GUS activity revealed that two upstream regions of the DRR206 promoter were particularly important for activation in the three plant species. Putative cis regulatory elements within the DRR206 promoter included a wound/pathogen-

inducible box (W/P-box) and a WRKY box (W-box). Gel shift assays with nuclear extracts from treated and untreated tissue with the W/P-box revealed both similar and unique protein-DNA complexes from pea, potato, and tobacco. Tobacco was stably transformed with gene constructs of the DRR206 promoter fused with a DNase elicitor gene from Fusarium solani f. sp. phaseoli, FsphDNase. Pathogenicity tests indicated that the FsphDNase elicitor conferred resistance against Pseudomonas syringae pv. tabaci and Alternaria alternata in tobacco. Transgenic potatoes showed some sensitivity to the FsphDNase gene providing less protection against Phytophthora infestans. Thus, the elicitor-coding gene, FsphDNase, is capable of generating resistance in a heterologous plant system (tobacco) when fused with defined regions of the pea DRR206 promoter.
\end{abstract}

In the majority of plant-pathogen interactions, plants mount a rapid disease resistance response (DRR) known as nonhost resistance, a type of general resistance that is difficult to define due to its complexity, involving multiple signals and genes (22). Nonhost resistance occurs when pathogens or pathogen-derived signal molecules (elicitors) trigger the surveillance system of the plant, activating a spectrum of defense genes, thus preventing pathogen invasion. The mechanisms for inducing nonhost disease resistance are not well known $(32,46)$. In contrast, $\mathrm{R}$ gene-mediated race-specific resistance is more simply defined in that it occurs in response to the recognition of a host $\mathrm{R}$ gene-associated product and a corresponding avirulence (Avr) gene product of the pathogen.

In plants, recognition between the host $\mathrm{R}$ gene product and the corresponding Avr gene product results in a heightened intensity of pathogenesis-related (PR) gene induction. Yet recent attempts to genetically engineer disease resistance by overexpressing individual PR genes have usually resulted in little or incomplete resistance (36). A more complete resistance may be possible by inducing a broader array of PR genes, as is typical of the nonhost resistance response. To facilitate this process, some type of trigger would be necessary to activate this natural defense mechanism. One such elicitor, a DNase, has been derived from the fungal pathogen, Fusarium solani f. sp. phaseoli (FsphDNase). FsphDNase is exuded by the fungus in the presence of the pea host (18) and detected in cytosolic extracts of pea following inoculation of $F$. solani on pea tissue (28). When purified FsphDNase is applied to pea endocarp tissue, the tissue becomes

Corresponding author: L. A. Hadwiger; E-mail address: chitosan@mail.wsu.edu

Publication no. P-2004-0422-01R

(C) 2004 The American Phytopathological Society immune to the true pea pathogen, $F$. solani f. sp. pisi (20), and the pea DRR206 gene (along with other PR genes) is induced (5). A gene coding for FsphDNase has been cloned (GenBank Accession No. AF175291) (28) and thus is available for genetic transfer to a plant of interest. Inducible expression of FsphDNase is essential because constitutive activation of FsphDNase within the plant cell may be destructive, as has been described in other gene transfers (23). The promoter driving its expression should be induced at low levels in response to wounding and environmental stresses, but activated rapidly to maximum levels when challenged by a pathogen or elicitors released from the pathogen.

The disease resistance gene DRR206 (7) from pea (Pisum sativum L.) encodes a protein that shares homology with a dirigent protein involved in lignin/lignan biosynthesis $(9,17)$. Lignan has antifungal properties, while lignin is an important part of the structural protection as well as defense. DRR206 gene expression is up-regulated during nonhost pathogen interactions with $F$. solani f. sp. phaseoli (a bean pathogen) and fungal components such as chitosan $(5,16,40)$. It is also activated in race-specific resistance against races of the bacterium Pseudomonas syringae pv. pisi (8) and with F. oxysporum (21). When the DRR206 gene is expressed constitutively in canola, increased resistance can be observed against a broad range of fungal pathogens including Sclerotinia sclerotiorum, Rhizoctonia solani, and Leptosphaeria maculans (51). In pea endocarp tissue, DRR206 is also induced by DNA-specific abiotic factors (5). Because of this multiplefactor inducibility, we further evaluated the DRR206 promoter.

As an initial step to evaluate the activity of the DRR206 promoter in a heterologous system, a construct of a $2.7-\mathrm{kb}$ segment of the DRR206 promoter fused with the $\beta$-glucuronidase (GUS) reporter gene was prepared and stably transformed into tobacco (5). Some differences in GUS activity in the heterologous system of tobacco were observed relative to that of pea when the 
DRR206 promoter was activated by treatments with abiotic elicitors (5). Because nuclear proteins interacting with the DRR206 promoter are also likely to vary between plant species, differences in the gene-activating responses between pea and other plants were expected. However, when the pea DRR206 promoter::GUS reporter was heterologously transferred to tobacco, biotic elicitors, including those released by a tobacco pathogen, activated this promoter as indicated by increased GUS activity. Therefore, the pea DRR206 promoter possesses features of universal regulation that can be used to develop disease-resistant plant species other than pea.

Herein, we examined the pea DRR206 promoter to define broad regions involved in wound and pathogen inducibility and to determine if this promoter is comparably functional in other plant species. DRR206 promoter activity was characterized by promoter deletion analyses and fusions of these deletions with the GUS reporter gene. GUS activity was monitored following transient transformation via agroinfiltration. Results of these experiments indicate that two segments $(2.7$ and $1.9 \mathrm{~kb})$ of the DRR206 promoter activated the GUS reporter in potato, tobacco, and pea. To evaluate a potential role of these promoter segments in the development of disease-resistant plants, tobacco and potato plants were transformed with constructs of the DRR206 promoter segments $(2.7$ and $1.9 \mathrm{~kb})$ fused with the elicitor-coding gene, FsphDNase. Resistance generated by these transgenic lines was effective in response to certain pathogens.

\section{MATERIALS AND METHODS}

DRR206 promoter deletion constructs. Primers were designed to amplify segments of the DRR206 gene sequence of approximately $400 \mathrm{bp}$, upstream of the DRR206 start site. For certain segments, restriction enzymes were used to obtain fragments of the desired length. Using the Genetics Computer Group program (Madison, WI), primers were designed for the $2.3 \mathrm{~kb}$ (P206F2/P206R), 1.4 kb (P206F4/P206R), and 500 bp (P206F6/ P206R) segments as follows: P206F2 (5'-ATTATACCATATTGGACCAGCC-3'), P206F4 (5'-TCCACAATTCACCCAACC-3'), P206F6 (5'-CACCTCTATCAACGTCATGGTC-3'), and P206R (5'-TTTATTTCTTAGCTATTGGAACTTG-3'). Each polymerase chain reaction (PCR) contained $0.1 \mu \mathrm{g}$ of DC206-16A pBS plas$\mathrm{mid} / 2.7-\mathrm{kb}$ promoter, $10 \mathrm{mM}$ Tris- $\mathrm{HCl}(\mathrm{pH} 9.0), 50 \mathrm{mM} \mathrm{KCl}$, $0.1 \%$ Triton X-100, $250 \mu \mathrm{M}$ dNTPs, $2.5 \mathrm{mM} \mathrm{MgCl}_{2}, 1 \mu \mathrm{l}$ each (1 pmol) of forward and reverse primers, and 1.5 units of Taq polymerase (Promega, Madison, WI) $\mu^{-1}$. PCR amplification was performed with a thermocycler (Hybaid PCRSprint; Midwest Scientific, Valley Park, MO) with an initial 2.5 -min step at $94^{\circ} \mathrm{C}$ followed by 30 cycles of $15 \mathrm{~s}$ at $94^{\circ} \mathrm{C}, 20 \mathrm{~s}$ at $55^{\circ} \mathrm{C}$, and $2 \mathrm{~min}$ at $72^{\circ} \mathrm{C}$, and a final extension of $7 \mathrm{~min}$ at $72^{\circ} \mathrm{C}$. Each fragment was cloned into the TA cloning vector pCR2.1 (Invitrogen, Carlsbad, $\mathrm{CA}$ ) as directed by the manufacturer. The $1.9-\mathrm{kb}$ fragment was derived from $P$ st $\mathrm{I} / \mathrm{Sca}$ I digestion, while the 850-bp fragment was derived from $N$ siI/ScaI digestion. Each of the fragments was subcloned into $\mathrm{pBS}$, sequenced, inserted into the binary vector pBI101 (Clonetech Labs, Palo Alto, CA), and electroporated into Agrobacterium tumefaciens (strain LBA4404) with a Gene Pulser II System (Bio-Rad Laboratories, Hercules, CA).

Agroinfiltration of DRR206 promoter::GUS constructs. Wild-type tobacco (Nicotiana tabacum L. cv. Xanthi) was seeded and grown for 8 weeks in a greenhouse. Solanum tuberosum L. cv. Russet Burbank was grown from tubers and maintained in a greenhouse for 7 weeks, while Pisum sativum L. was grown from seed in sand for approximately 2 weeks in a greenhouse. Agrobacterium tumefaciens containing the above-mentioned DRR206 deletion constructs were grown for 2 days in YEP (10 g of Bactoyeast extract, $10 \mathrm{~g}$ of Bacto-peptone, and $5 \mathrm{~g}$ of $\mathrm{NaCl}$ per liter) cultures to a final density adjusted to $A_{420}$ of 1.8 to 2 optical density in $5 \mathrm{~g}$ of Murashige and Skoog based salt mixture (MS),
$1.95 \mathrm{~g}$ of MES, and $20 \mathrm{~g}$ of sucrose liter $^{-1}$ supplemented with $200 \mu \mathrm{M}$ acetosyringone (Aldrich Chemical Co., Milwaukee, WI). Plants were agroinfiltrated with approximately $100 \mu \mathrm{l}$ of the bacterial suspensions. Leaf disks were harvested from the infiltrated areas with a cork borer at 1 to 6 days postinfiltration (dpi) and immediately frozen in liquid nitrogen.

GUS assays. Leaf disks were ground in liquid nitrogen with a pestle-tipped Dremel drill immediately followed by the addition of GUS extraction buffer $(50 \mathrm{mM} \mathrm{NaPO}, \mathrm{pH} 7 ; 10 \mathrm{mM}$ EDTA; $0.1 \%$ [vol/vol] sarcosyl; $0.1 \%$ [vol/vol] Triton X-100; and $10 \mathrm{mM}$ $\beta$-mercaptoethanol) at $177 \mu \mathrm{cm}^{-2}$ of leaf tissue. Ten microliters of plant extract was assayed for GUS activity by incubation for $15 \mathrm{~min}$ at $37^{\circ} \mathrm{C}$ with $150 \mu \mathrm{l}$ of $1.5 \mathrm{mM}$ 4-methylumbelliferyl- $\beta$ glucuronide (Sigma Chemical, St. Louis). The reaction was stopped with $0.2 \mathrm{M} \mathrm{Na}_{2} \mathrm{CO}_{3}$ in a final volume of $1.5 \mathrm{ml}$. Fluorescence was measured with a fluorometer (Model TKO 100; Hoefer Scientific, San Francisco) with an excitation of $365 \mathrm{~nm}$ and emission of $460 \mathrm{~nm}$.

Statistical analysis. GUS data were subjected to analysis of variance using the least significant difference model procedure of SAS (SAS Institute, Cary, NC).

Analysis of the DRR206 promoter for cis regulatory elements. Analyses of the DRR206 promoter region for putative cisacting elements entailed the use of several programs with default settings. The programs included BLAST (available online from the National Center for Biotechnology Information); TESS (44) (Transcription Element Search Software, available online from the Computational Biology and Informatics Laboratory, University of Pennsylvania); and TRANSFAC (Transcription Factor Database; available online from Biological Databases) containing eukaryotic cis- and trans-acting regulatory DNA elements.

Electrophoretic mobility shift assay. Pea nuclear proteins were extracted from 8-day-old seedlings that had been kept in the dark and either inoculated for $13 \mathrm{~h}$ with $F$. solani $\mathrm{f}$. sp. phaseoli or noninfected. Nuclear proteins were extracted from immature pea pods that were untreated or inoculated with $F$. solani f. sp. phaseoli for $6 \mathrm{~h}$. Tobacco leaves or potato leaflets were collected $6 \mathrm{~h}$ after they were wounded with a $3 \mathrm{MM}$ abrasive sponge, treated with chitosan $\left(1 \mathrm{mg} \mathrm{ml}^{-1}\right)$ and wounded with an abrasive sponge, or untreated. Tissue was ground using a Waring blender or mortar and pestle with liquid nitrogen. Nuclear proteins were isolated according to Jensen et al. (25) with modifications. Three milliliters of cold buffer A $(10 \mathrm{mM} \mathrm{NaCl}, 10 \mathrm{mM}$ MES-NaOH [pH 6.0], $5 \mathrm{mM}$ EDTA, $0.15 \mathrm{mM}$ spermine, $0.5 \mathrm{mM}$ spermidine, $0.6 \%$ Triton X-100 [vol/vol], $0.25 \mathrm{M}$ sucrose, $20 \mathrm{mM} \beta$-mercaptoethanol, and $0.2 \mathrm{mM}$ phenylmethylsulfonyl fluoride) was added for each gram of fresh tissue. The crude extract was filtered through two layers of Miracloth (Calbiochem, San Diego) and centrifuged for $5 \mathrm{~min}$ at $4,000 \times g$. The pellet was suspended in $0.5 \mathrm{ml}$ of buffer B/NP-40 $\mathrm{g}^{-1}$ (10 mM MES-NaOH [pH 6.0], $260 \mathrm{mM}$ sucrose, $10 \mathrm{mM} \mathrm{NaCl}, 1 \mathrm{mM}$ EDTA, $0.15 \mathrm{mM}$ spermine, $0.5 \mathrm{mM}$ spermidine, $0.1 \%$ Nonidet P-40 [ $\mathrm{vol} / \mathrm{vol}$ ], and $14.3 \mathrm{mM}$ $\beta$-mercaptoethanol) and repeated. Nuclei were pelleted by centrifugation and resuspended in buffer $\mathrm{C}(20 \mathrm{mM}$ HEPES-KOH $[\mathrm{pH}$ 7.9], $0.2 \mathrm{mM}$ EDTA, $420 \mathrm{mM} \mathrm{NaCl}$, and $1.5 \mathrm{mM} \mathrm{MgCl}_{2}$ ) and then were lysed by sonication for $1 \mathrm{~min}$. After $30 \mathrm{~min}$ on ice, samples were centrifuged for $15 \mathrm{~min}$ at $12,000 \times g$, and the supernatant was quantified with a Bradford assay. Glycerol was added to the extract to $20 \%(\mathrm{vol} / \mathrm{vol})$ and stored at $-70^{\circ} \mathrm{C}$.

Two complementary single-stranded 18-mer oligonucleotides (5'-CCTTCCACCATACCTTTA-3' and 5'-GGTGTAAAGGTATGGTGG-3') were synthesized (Operon Technologies, Alameda, CA) and annealed in equimolar amounts to obtain the wound/ pathogen-inducible region (W/P-box) $-1,209$ to $-1,188$. This resulted in a double-stranded 22 mer with 4-bp overhangs for end labeling. The end-labeling reaction contained Klenow ( $3 \mathrm{u})$, approximately $1 \mu \mathrm{g}$ of double-stranded W/P-box oligomer, $1 \times$ buffer minus dATP (-dATP) (Ambion, Austin, TX), and $\left[{ }^{32} \mathrm{P}\right] \mathrm{dATP}$ 
(20 to $40 \mu \mathrm{Ci}$ ) with a specific activity of $3,000 \mathrm{Ci} \mathrm{mmol}^{-1}$. The reaction mix was incubated for $30 \mathrm{~min}$ at $37^{\circ} \mathrm{C}$ and separated on a Sephadex G-50 column to remove unincorporated nucleotides. For the W-box probe, complementary oligonucleotides of 18 bases in length containing a single WRKY box (W-box) (5'-TTGACTAAACGTCATGGT-3' and 5' ${ }^{\prime}$-TAAGACCATGACGTTTAG-3') were synthesized (Operon Technologies) and annealed. The W-box probe was end-labeled as described previously.

The conditions of the gel shift experiments were essentially those described by Jensen et al. (25). The binding reaction mix for 30 to $40 \mu \mathrm{l}$ contained $3.5 \mathrm{pmol}$ of end-labeled DNA probe, $25 \mathrm{mM}$ HEPES (pH 7.9), $10 \mathrm{mM} \mathrm{CaCl}_{2}, 1 \mathrm{mM}$ dithiothreitol (DTT), $10 \%$ (vol/vol) glycerol, $10 \mu \mathrm{g}$ of nuclear extract, and competitors $(\mathrm{dA} / \mathrm{dT}[1 \mu \mathrm{g}], \mathrm{dI} / \mathrm{dC}[1 \mu \mathrm{g}]$, or unlabeled cold probe as specified). This was incubated for $20 \mathrm{~min}$ at room temperature and loaded on $6 \%$ polyacrylamide gel in $1 \times$ TGE buffer (1 liter of 10x TGE buffer contains $30.3 \mathrm{~g}$ of Trizma base, $142.7 \mathrm{~g}$ of glycine, and $20 \mathrm{ml}$ of $0.5 \mathrm{M}$ EDTA). Electrophoresis was performed at $150 \mathrm{~V}$ for $2 \mathrm{~h}$. Following electrophoresis, gels were dried under vacuum at $60^{\circ} \mathrm{C}$ for approximately $30 \mathrm{~min}$. Gels were autoradiographed overnight at $-70^{\circ} \mathrm{C}$ with an intensifier screen or at room temperature without an intensifier screen.

Inoculation of pea tissue with pathogens. Each of the pathogens, except $P$. infestans, were grown on potato dextrose agar (PDA) and allowed to sporulate. Phytophthora infestans (US\#8) sporangia were maintained on infected potato leaflets. Spores were scraped from the plate or rinsed from infected potato leaflets and suspended in sterile water. Immature pea pods ranging from 1 to $2 \mathrm{~cm}$ in length were split and challenged on the inner endocarp surface with the following pathogens: Colletotrichum coccodes $\left(6.6 \times 10^{6}\right.$ spores $\left.\mathrm{ml}^{-1}\right)$, Verticillium dahliae $\left(2 \times 10^{7}\right.$ spores $\left.\mathrm{ml}^{-1}\right)$, Phytophthora infestans $\left(4 \times 10^{5}\right.$ spores $\left.\mathrm{ml}^{-1}\right)$, Rhizoctonia solani $\left(4 \times 10^{5}\right.$ spores $\left.\mathrm{ml}^{-1}\right)$, Fusarium solani $\mathrm{f}$. sp. pisi $\left(1.6 \times 10^{6}\right.$ spores $\left.\mathrm{ml}^{-1}\right)$, or $F$. solani f. sp. phaseoli $\left(1.6 \times 10^{6}\right.$ spores $\left.\mathrm{ml}^{-1}\right)$ for 3 and $6 \mathrm{~h}$.

RNA isolation and northern blotting. RNA was extracted according to Chomczynski and Sacchi (6) with modifications. About $150 \mathrm{mg}$ of tissue was frozen in liquid nitrogen and ground with $1 \mathrm{ml}$ of extraction buffer $(0.8 \mathrm{M}$ guanidine thiocyanate; $0.4 \mathrm{M}$ ammonium thiocyanate; $0.1 \mathrm{M}$ sodium acetate, $\mathrm{pH} 5 ; 5 \%$ [vol/vol] glycerol; and $38 \%$ [vol/vol] water-saturated acid phenol, $\mathrm{pH}$ 4.0). The mixture was incubated with $200 \mu \mathrm{l}$ of chloroform at room temperature for 2 to $15 \mathrm{~min}$ and centrifuged at $10,000 \times g$ for $15 \mathrm{~min}$. The supernatant was removed, and RNA was precipitated. After centrifugation at $10,000 \times g$ for $10 \mathrm{~min}$, the pellet was suspended in $0.1 \%$ ( $\mathrm{vol} / \mathrm{vol})$ diethyl pyrocarbonate-treated water.

Ten micrograms of total RNA was electrophoresed on a $1.2 \%$ agarose gel with $0.67 \mathrm{M}$ formaldehyde. RNA was blotted in 10X SSC (1.5 M NaCl and $150 \mathrm{mM}$ trisodium citrate) onto a Hybond $\mathrm{N}$ nylon membrane (Amersham). Membranes were incubated at $60^{\circ} \mathrm{C}$ overnight in prehybridization solution (10× Denhardt's solution [50× Denhardt's is $1 \%$ (wt/vol) polyvinylpyrrolidone, $1 \%(\mathrm{wt} / \mathrm{vol})$ bovine serum albumin fraction $\mathrm{V}$, and $1 \%(\mathrm{wt} / \mathrm{vol})$ Ficoll 400]; $3 \times$ SSC; $10 \%$ [wt/vol] dextran sulfate; $7 \%$ [wt/vol] sodium dodecyl sulfate [SDS]; and $150 \mu \mathrm{g}$ of single-stranded salmon sperm DNA ml${ }^{-1}$ ). A 513-bp FsphDNase genomic clone was labeled with a random primer labeling kit (DECAprime II; Ambion) according to the manufacturer's instructions using $50 \mu \mathrm{Ci}\left[{ }^{32} \mathrm{P}\right] \mathrm{dATP}$ with specific activity of $3,000 \mathrm{Ci} \mathrm{mmol}^{-1}$. The labeled probe was spun on a Sephadex 50 to 150 column to remove excess $\left[{ }^{32} \mathrm{P}\right] \mathrm{dATP}$. The labeled probe was added to the prehybridization solution and incubated for 18 to $24 \mathrm{~h}$ at $60^{\circ} \mathrm{C}$. Membranes were washed twice in $2 \times \mathrm{SSC}$ (for $20 \times, 3 \mathrm{M} \mathrm{NaCl}$, $0.3 \mathrm{M}$ trisodium citrate) containing $0.1 \%$ (wt/vol) SDS for $15 \mathrm{~min}$ at room temperature, and twice more for $15 \mathrm{~min}$ at the hybridization temperature. For northerns involving detection of the pea DRR206 message, $5 \mu \mathrm{g}$ of total RNA was electrophoresed, blotted, and probed as described previously (5). Membranes were exposed overnight to X-Omat Blue film (Kodak, Rochester, NY) with an intensifier screen at $-70^{\circ} \mathrm{C}$.

Preparation of DRR206 promoter::FsphDNase constructs. The 7.1 constructs contained the $2.7-\mathrm{kb}$ segment of the DRR206 promoter fused to FsphDNase with and without the GUS gene, respectively. The 8.1 constructs contained the $1.9-\mathrm{kb}$ segment of the DRR206 promoter fused to FsphDNase with and without GUS, respectively. Each was ligated into the binary vector, pBI101, following removal of the GUS gene. Subsequently, the constructs were electroporated into Agrobacterium tumefaciens strain LBA4404 and selected on YEP plates containing kanamycin $\left(100 \mu \mathrm{g} \mathrm{liter}^{-1}\right)$ and streptomycin $\left(100 \mu \mathrm{g} \mathrm{liter}^{-1}\right)$. A single colony was inoculated into $2 \mathrm{ml}$ of YEP supplemented with kanamycin and streptomycin (each $100 \mu \mathrm{g} \mathrm{ml}^{-1}$ ) and grown for 1 day. The culture was transferred to $50 \mathrm{ml}$ of YEP with kanamycin and streptomycin (each $100 \mu \mathrm{g} \mathrm{ml}^{-1}$ ). Overnight bacterial suspensions were centrifuged at $1,000 \times g$ for $10 \mathrm{~min}$. The bacteria were resuspended in YEP.

Stable transformation of DRR206 promoter::FsphDNase constructs. Agrobacterium tumefaciens containing the DRR206:: FsphDNase constructs were incubated with leaf disks from $N$. tabacum cv. Xanthi in YEP medium for approximately $30 \mathrm{~s}$. Leaf disks were placed onto co-cultivation media (MS salts, $30 \mathrm{~g}$ of kinetin liter ${ }^{-1}, 0.3 \mathrm{mg}$ of benzyl adenine purine [BAP] liter ${ }^{-1}$, and $1.8 \mathrm{~g}$ of phytagel liter ${ }^{-1}$ ). After 3 days, the disks were transferred to the selection media (same as the co-cultivation media, except supplemented with $30 \mathrm{~g}$ of sucrose liter $^{-1}, 50 \mathrm{mg}$ of kanamycin liter ${ }^{-1}, 250 \mathrm{mg}$ of carbenicillin liter ${ }^{-1}$, and B5 vitamin, $\mathrm{pH}$ 5.7). When shoots became visible, they were transferred onto MS rooting media (MS salts, $30 \mathrm{~g}$ of sucrose liter ${ }^{-1}, 250 \mathrm{mg}$ of carbenicillin liter ${ }^{-1}, 50 \mathrm{mg}$ of kanamycin liter $^{-1}, 1.8 \mathrm{~g}$ of phytagel $\operatorname{liter}^{-1}$, B5 vitamin, $\mathrm{pH}$ 5.6). Only those that continued to root on kanamycin $\left(\mathrm{T}_{0}\right)$ were transported to a greenhouse and screened with Pseudomonas syringae pv. tabaci at $2 \times 10^{5} \mathrm{CFU} \mathrm{ml^{-1 }}$. $\mathrm{T}_{0}$ plants showing delayed, increased resistance to wildfire symptoms caused by Pseudomonas syringae pv. tabaci were selfed to collect the $\mathrm{T}_{1}$ generation. The seeds from the $\mathrm{T}_{1}$ lines were plated on $1 / 2 \mathrm{MS}$ ( $30 \mathrm{~g}$ of sucrose and $1.8 \mathrm{mg}$ of phytagel liter ${ }^{-1}$ ) with $300 \mathrm{mg}$ of kanamycin liter $^{-1}$. Those that grew vigorously were screened with Pseudomonas syringae pv. tabaci at three different concentrations $\left(1 \times 10^{7}, 1 \times 10^{5}\right.$, and $\left.1 \times 10^{3} \mathrm{CFU} \mathrm{ml}^{-1}\right)$. Those exhibiting resistance were selfed and the $T_{2}$ generation was collected. Seeds collected from tobacco were surface-sterilized and plated on 1/2MS containing $300 \mathrm{mg}$ of kanamycin liter ${ }^{-1}$.

Russet Burbank potatoes were maintained on propagation and rooting medium (MS salts, vitamin B5, MSVI vitamins [2 $\mathrm{mg}$ of glycine liter ${ }^{-1}, 0.5 \mathrm{mg}$ of nicotinic acid liter $^{-1}, 0.5 \mathrm{mg}$ of pyridoxin- $\mathrm{HCl}$ liter $^{-1}$, and $0.4 \mathrm{mg}$ of thiamine-HCl liter ${ }^{-1}$ ], JHMS vitamin [0.25 mg of folic acid and $0.05 \mathrm{mg}^{-1}$ d-biotin liter ${ }^{-1}$, $100 \mathrm{mg}$ of inositol liter ${ }^{-1}, 0.02 \mathrm{mg}$ of 2-naphthalene acetic acid [NAA] liter ${ }^{-1}, 30 \mathrm{~g}$ of sucrose liter ${ }^{-1}$, and $6 \mathrm{~g}$ of agar liter ${ }^{-1}, \mathrm{pH}$ 5.6). Sections of internodes, petioles, and leaflets containing the major vein were cut into YEP and transformed with Agrobacterium tumefaciens containing each construct as described previously. The sections were placed on plates containing callusinducing medium (MS salt, MSVI and JHMS vitamins, $100 \mathrm{mg}$ of inositol liter ${ }^{-1}, 30 \mathrm{~g}$ of sucrose liter ${ }^{-1}, 1 \mathrm{mg}$ of BAP liter ${ }^{-1}, 2 \mathrm{mg}$ of NAA liter ${ }^{-1}, 50 \mathrm{mg}$ of kanamycin liter ${ }^{-1}$, and $6 \mathrm{~g}_{\text {of agar }}$ liter $^{-1}$, $\mathrm{pH}$ 5.6). The explants were transferred onto 3C5ZR medium (MS salts [pH 5.9], vitamins [ $1 \mathrm{mg}$ of thiamine- $\mathrm{HCl}$ liter ${ }^{-1}, 0.5 \mathrm{mg}$ of nicotinic acid liter ${ }^{-1}$, and $0.5 \mathrm{mg}$ of pyridoxine- $\mathrm{HCl}$ liter $\left.^{-1}\right]$, $100 \mathrm{mg}$ of myo-inositol liter ${ }^{-1}, 3 \mu \mathrm{M}$ indole acetic acid, $5 \mathrm{mM}$ trans-zeatin riboside, $30 \mathrm{~g}$ of sucrose $\operatorname{liter}^{-1}, 8 \mathrm{~g}$ of agar $\operatorname{liter}^{-1}$, $50 \mathrm{mg}$ of kanamycin liter ${ }^{-1}$, and $100 \mathrm{mg}$ of timentin liter $^{-1}$ ) and incubated at $25^{\circ} \mathrm{C}$ with a $16 \mathrm{~h}$ photoperiod. The regenerated shoots were excised and transferred to rooting medium (MS salt, MSVI vitamins, JHMS vitamins, $100 \mathrm{mg}$ of inositol liter ${ }^{-1}, 30 \mathrm{~g}$ 
of sucrose liter ${ }^{-1}, 0.02 \mathrm{mg}$ of NAA liter ${ }^{-1}, 6 \mathrm{~g}$ of agar liter ${ }^{-1}$, and $100 \mathrm{mg}$ of kanamycin liter ${ }^{-1}$, $\mathrm{pH}$ 5.6) to induce root formation. Regenerated shoots showing vigorous root growth in kanamycincontaining media were propagated and transplanted in a greenhouse.

DNA isolation and PCR screening of transgenics. DNA was isolated as outlined by Karcher (27). The DNA was redissolved in $100 \mu \mathrm{l}$ of $1 \mathrm{mM}$ Tris and $0.1 \mathrm{mM}$ EDTA, $\mathrm{pH}$ 8.0. Screening of each of the transgenic lines was performed with gene-specific primers designed for FsphDNase 22KDGS3P-1 (5'- CTACCGCTATCATGGCCTTTGTC-3') and W822REV (5'-CAGGGTGGTGATGAGGTGAG-3') and amplified a fragment of $481 \mathrm{bp}$. Each PCR reaction consisted of $10 \mathrm{ng}$ of genomic DNA, $10 \mathrm{mM}$ Tris$\mathrm{HCl}$ (pH 9.0), $50 \mathrm{mM} \mathrm{KCl}, 0.1 \%$ (vol/vol) Triton X-100, $250 \mu \mathrm{M}$ dNTPs, $2.5 \mathrm{mM} \mathrm{MgCl}_{2}, 1 \mu \mathrm{l}$ each (1 pmol) forward and reverse primers, and 1.5 units of Taq polymerase (Promega). Separate reactions were performed with genomic DNA from the wild-type tobacco (- control) and $F$. solani (+ control). PCR amplification was performed with an initial 3 -min step at $94^{\circ} \mathrm{C}$ followed by 25 cycles of $30 \mathrm{~s}$ at $94^{\circ} \mathrm{C}, 30 \mathrm{~s}$ at $60^{\circ} \mathrm{C}$, and $1.5 \mathrm{~min}$ at $72^{\circ} \mathrm{C}$, and a final extension of $7 \mathrm{~min}$ at $72^{\circ} \mathrm{C}$.

Pathogenicity tests. For screening of tobacco lines, rifampicinresistant Pseudomonas syringae pv. tabaci was grown on nutrient broth-yeast (NBY) extract (for 1 liter, $8 \mathrm{~g}$ of nutrient broth, $2 \mathrm{~g}$ of yeast extract, $2 \mathrm{~g}$ of $\mathrm{K}_{2} \mathrm{HPO}_{4}$ anhydrous, $0.5 \mathrm{~g}$ of $\mathrm{KH}_{2} \mathrm{PO}_{4}, 15 \mathrm{~g}$ of Bacto-agar, $50 \mathrm{ml}$ of $10 \%$ [wt/vol] glucose, and $1 \mathrm{ml}$ of $1 \mathrm{M}$ $\mathrm{MgSO}_{4}$ ) supplemented with rifampicin (100 mg liter $\left.{ }^{-1}\right)$. Colonies were scraped from the plates and suspended in sterile water to attain an optical density of $A_{420}=0.3$, the equivalent of $1 \times$ $10^{8} \mathrm{CFU} \mathrm{m} \mathrm{^{-1 }}$. The bacterial suspension was further diluted to $1 \times$ $10^{7}, 1 \times 10^{5}$, and $1 \times 10^{3} \mathrm{CFU} \mathrm{ml}{ }^{-1}$ to perform screening of the $\mathrm{T}_{0}$ and $\mathrm{T}_{1}$ transgenic tobacco lines.

For inoculations and subsequent colony counts, concentrations of rifampicin-resistant Pseudomonas syringae pv. tabaci were adjusted to $1 \times 10^{5} \mathrm{CFU} \mathrm{ml}{ }^{-1}$ in sterile water, and $100 \mu \mathrm{l}$ of the suspension was infiltrated into tobacco leaves with a needleless syringe in two areas per leaf, per plant. Four plants were used in each experiment, and the experiment was repeated at least three times for each time point. Eight leaf disks $(1.5 \mathrm{~cm}$ in diameter) were combined and ground in a mortar and pestle with $1 \mathrm{ml}$ of phosphate buffer (12.5 mM, pH 7.1). A 1:10 dilution series was prepared in phosphate buffer, and $100 \mu$ l of each dilution was plated on NBY medium supplemented with rifampicin $(100 \mathrm{mg}$ liter $^{-1}$ ). Population counts of Pseudomonas syringae pv. tabaci were conducted at 1,3 , and 5 dpi.

Alternaria alternata (Fr.:Fr.) Keissl. longipes spores were harvested in sterile water and the concentration was adjusted to $1 \times$ $10^{5}$ spores $\mathrm{ml}^{-1}$. Fifty microliters of the spore suspension was pipetted on sterile $1 \mathrm{~cm}^{2}$ Whatman filter squares and placed on immature tobacco leaves that had been misted with water. Immature leaves were placed in humid chambers for 7 to 8 days at room temperature. This was repeated with a total of six plants from each of the transgenic tobacco lines.

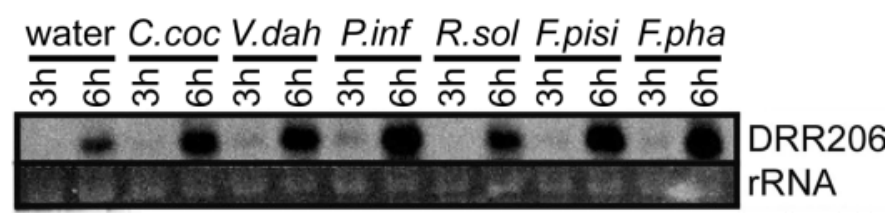

Fig. 1. Northern analysis of defense gene DRR206 expression in pea pod tissue following challenge with various plant pathogens: Colletotrichum coccodes $\left(6.6 \times 10^{6}\right.$ spores $\left.\mathrm{ml}^{-1}\right)$, Verticillium dahliae $\left(2 \times 10^{7}\right.$ spores $\left.\mathrm{ml}^{-1}\right)$, Phytophthora infestans $\left(4 \times 10^{5}\right.$ spores $\left.\mathrm{ml}^{-1}\right)$, Rhizoctonia solani $\left(4 \times 10^{5}\right.$ spores $\left.\mathrm{ml}^{-1}\right)$, Fusarium solani $\mathrm{f}$. sp. pisi $\left(1.6 \times 10^{6}\right.$ spores $\left.\mathrm{ml}^{-1}\right)$, and $F$. solani $\mathrm{f}$. sp. phaseoli $\left(1.6 \times 10^{6}\right.$ spores $\left.\mathrm{ml}^{-1}\right)$ for 3 and $6 \mathrm{~h}$. The blot was hybridized with a ${ }^{32}$ P-labeled 800-bp fragment of gene DRR206. Ethidium bromide staining of rRNA is shown.

\section{RESULTS}

Previous work indicated that pea gene DRR206 can be activated by various elicitors as well as compatible and incompatible pathogens (5). To further document the range of this response, immature pea endocarp tissues were challenged with various potato pathogens (Fig. 1). Each of these pathogens induced accumulation of the DRR206 message at $6 \mathrm{~h}$ postinoculation (Fig. 1). As noted previously (5), a lower level of the DRR206 gene activation occurs at $6 \mathrm{~h}$ in pea pods, probably as a result of handling, harvesting, splitting, and water treatment (Fig. 1).

To discern the important $c i s$-acting regions of the DRR206 promoter, segments of the promoter were fused upstream of the GUS reporter gene and transiently transferred to three different plants by agroinfiltration (Fig. 2) as a preliminary assay of the regions contributing to activation. The nomenclature for each of these different fragments was derived from the estimated size, namely $2.7 \mathrm{~kb}, 2.3 \mathrm{~kb}, 1.9 \mathrm{~kb}, 1.4 \mathrm{~kb}, 850 \mathrm{bp}$, and $500 \mathrm{bp}$. Overall, the transient transformation data from tobacco, potato, and pea indicated that the use of the full-length $2.7-\mathrm{kb}$ and the $1.9-\mathrm{kb}$ fragments resulted in a significant activation of the GUS reporter
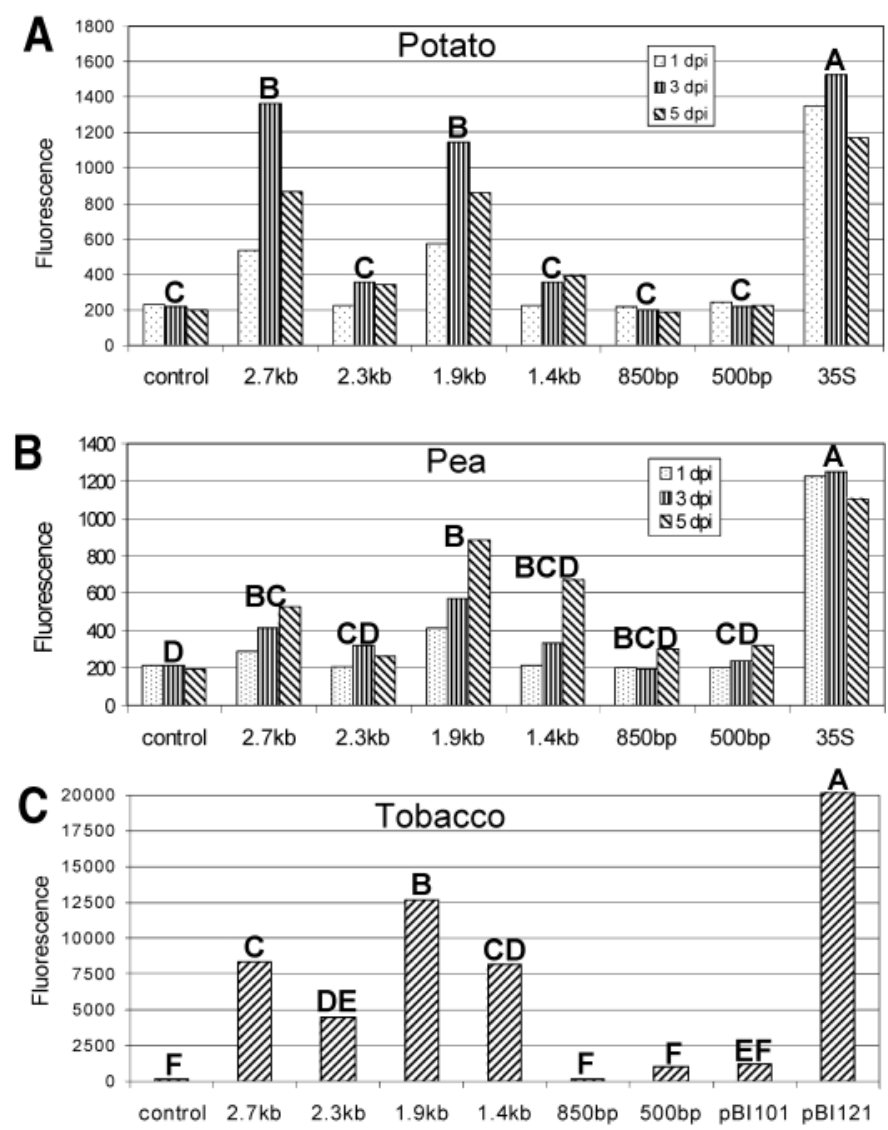

Fig. 2. Agroinfiltration of $\mathbf{A}$, potato, $\mathbf{B}$, pea, and $\mathbf{C}$, tobacco leaves with constructs of DRR206 promoter segments $(2.7 \mathrm{~kb}, 2.3 \mathrm{~kb}, 1.9 \mathrm{~kb}, 1.4 \mathrm{~kb}, 850 \mathrm{bp}$, and $500 \mathrm{bp}$ ) fused with the $\beta$-glucuronidase (GUS) reporter gene. Units of fluorescence indicate reporter gene activity as observed in GUS assays. Each assay for potato and pea was performed with three leaf disks from three plants for each time point (1, 3, and 5 days postinfiltration [dpi]). For potato, the assays were replicated in triplicates, and for pea, the assays were replicated twice. Means of the three time points with the same letter are not significantly different according to Fisher's protected least significant difference (LSD) test $(P=0.05)$. For tobacco, four plants were analyzed at $6 \mathrm{dpi}$ in each experiment, and data represent the combined analyses from three experiments. Means with the same letter are not significantly different according to Fisher's protected LSD $(P=0.05)$. Control = nontransformed plants; $35 \mathrm{~S}=$ 35S::GUS construct; pBI101 = promoterless construct; and pBI121 = constitutive $35 \mathrm{~S}$ promoter construct. 
gene (Fig. 2A to C). The presence of Agrobacterium tumefaciens alone as a foreign entity served as inherent sources of elicitation, thus indicating that the level of the plants' enhanced response was related to the promoter segment. GUS assays of tobacco leaves infiltrated with the various constructs indicated that the promoter activity was significantly greater when the 2.7-, 2.3-, 1.9-, and 1.4-kb promoter segments were driving GUS reporter gene expression (Fig. 2C). In contrast, GUS activity decreased markedly in the constructs containing only the 850- and 500-bp segments of the DRR206 promoter. Some variability in the potential to activate GUS expression was observed between older plants and younger plants and leaves. Nevertheless, the results were highly repeatable with similarly aged plants at 2 to 6 dpi using the uppermost leaves that were almost fully expanded.

The DRR206 promoter::GUS constructs were also transferred to potato and pea (Fig. 2A and B). Both resulted in a generally lower level of GUS activity and a slightly different pattern of induction than that of tobacco. To optimize the period of promoter activation in potato and pea, leaf disks were harvested at 1,3, and $5 \mathrm{dpi}$. In potato and pea, only the 2.7 - and $1.9-\mathrm{kb}$ promoter driving the GUS reporter gene were capable of causing a significant increase in GUS activity compared to the background levels of the control.

The transformation data (Fig. 2) indicated that certain regions of the DRR206 promoter may also be responsible for repression of GUS activity. Decreases in GUS activity were evident between the 2.3- and 1.9-kb segment and also between the 850- and 500-bp segments. Examination of the 2.3- to 1.9-kb sequence using TESS (Transcription Element Search Software) revealed potential recognition sites for repressors in these regions. In contrast, levels of reporter gene activation declined in tobacco when the segment between $1.4 \mathrm{~kb}$ and $850 \mathrm{bp}$ was deleted (Fig. 2 ), suggesting that enhancer regions are located immediately upstream of the 850-bp segment and in the vicinity of the $1.4-\mathrm{kb}$ region.

Examination of the sequence between the 1.4-kb and 850-bp segment indicated the presence of a W/P-box at $-1,199$, having the sequence TTACCTTCT $(34,54)$ with the consensus sequence underlined (Fig. 3). A W-box element (TGAC-N ${ }_{x}-$ GTCA) (42) is located at -231 to -219 . Other putative cis-acting elements of the pea DRR206 gene promoter that may be involved in defense are symbolized and listed in Figure 3.
GUS activity declined when the region between the $1.4-\mathrm{kb}$ and 850-bp segments of the DRR206 promoter was deleted (Fig. 2). Potentially, this may have been due to the absence of the W/Pbox, which resides in this region. Therefore, gel shift assays were performed with a single copy of the W/P-box to detect nuclear protein binding. As shown in Figure 4, nuclear proteins from pea seedlings bound to the 22-bp fragment containing a single W/Pbox. The low mobility complexes (upper bands) were competed away with increasing concentrations of cold probe (Fig. 4, lanes 7 to 10), indicating that the binding was specific for these complexes. These same proteins bound to the 22-bp W/P-box fragment with differing affinities when incubated with the nuclear extracts from induced or noninduced pea pod tissue (Fig. 4, lanes 2 and 3). In comparison to the W/P-box, binding of pea nuclear proteins with the 22-bp fragment containing a single copy of the W-box revealed only a single protein band-DNA complex (Fig. 4, lane 2). The band was competed away with increasing concentrations of cold probe (Fig. 4, lanes 3 to 5).

The binding affinity of pea seedling nuclear extracts to the 22-bp oligonucleotide probe (W/P-box) in comparison with extracts from potato leaves or pea pod tissue was sufficiently intense to obscure individual complexes. Therefore, a nonspecific competitor, poly[dA/dT], was added at $1 \mu \mathrm{g}$ to the pea pod and seedling nuclear extract (Fig. 5, lanes 2 to 4 ) to more clearly resolve these bands. Tobacco nuclear proteins also had a relatively high affinity and therefore $0.5 \mu \mathrm{g}$ of poly[dA/dT] was added to increase the resolution of the complex (Fig. 5, lanes 8 to 10). When the migration patterns of the complexes between the W/P-box and the nuclear extracts from the three different plant species were compared, different patterns of protein-DNA complexes were observed (Fig. 5). For example, in potato, the same numbers of protein-DNA complexes were observed between wounded and untreated tissues. However, the intensity of several complexes increased when the leaves were wounded and treated with chitosan (Fig. 5, lanes 6 and 7) relative to the untreated control (Fig. 5, lane 5). That pattern was different than the binding pattern observed between the W/P-box and tobacco nuclear extracts (Fig. 5, lanes 8 to 10). In this instance, the low mobility complexes (upper bands) were undetectable while the faster migrating complex (lower band) increased in intensity when the leaves were wounded and chitosan was applied (Fig. 5, lanes 9 and 10). In contrast, gel shift assays with pea pod extracts (Fig. 5, lanes 2 and 3) revealed

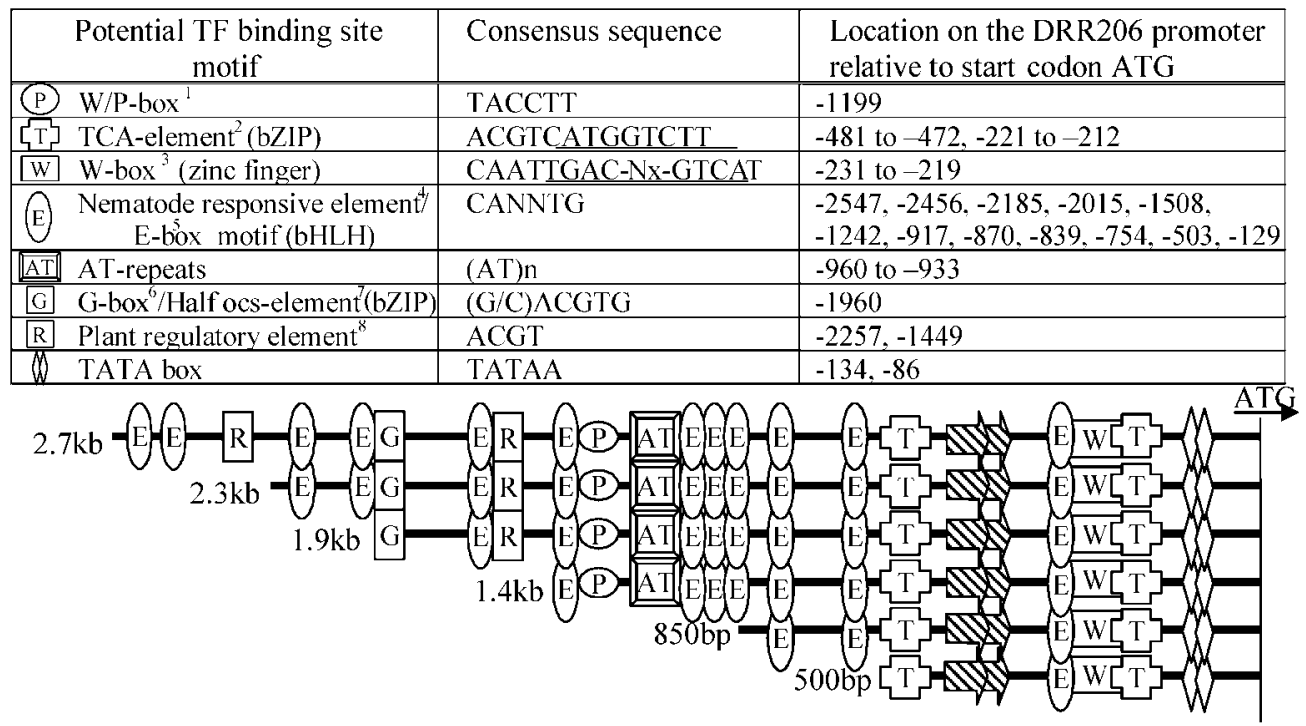

Fig. 3. Schematic representations of the putative cis-acting elements present in the pea DRR206 promoter sequence and the lengths of the various promoter segments used in this study. Elements are shown as stated, two hashed arrows (two perfect repeats). ${ }^{1}$ Palm et al. (34) and Wu et al. (53); ${ }^{2}$ Goldsbrough et al. (19); ${ }^{3}$ Rushton and Somssich (42); ${ }^{4}$ Puzio et al. (37) and Escobar et al. (12); ${ }^{5}$ Baker et al. (1); ${ }^{6}$ Buttner and Singh (3); ${ }^{7}$ DeGreve et al. (10); and ${ }^{8}$ Foster et al. (15) and Singh et al. (45). 
that the lower mobility DNA-protein complex exhibited substantially reduced binding affinity when challenged with $F$. solani f. sp. phaseoli. A similar slow migrating complex was abolished when tobacco was wounded or treated with chitosan.

To examine the role of the pea DRR206 promoter in the generation of disease resistance in a heterologous plant system, tobacco and potato were stably transformed with gene fusions of the DRR206 promoter (2.7- and 1.9-kb segments) and a cDNA encoding the FsphDNase elicitor. PCR screenings were conducted and plants lacking the 481-bp PCR product were terminated. When the DRR206 promoter::FsphDNase gene fusion was stably expressed in tobacco and challenged with Pseudomonas syringae pv. tabaci, decreased numbers of colony forming units were observed following dilution plating at 3 dpi (Fig. 6A) relative to the control plant, $\mathrm{pBI}$. Disease spread was readily evident on tobacco leaves not containing the DRR206 promoter::FsphDNase construct when inoculated at $2 \times 10^{5}$ and $2 \times$ $10^{7} \mathrm{CFU} \mathrm{ml} \mathrm{m}^{-1}$ of Pseudomonas syringae pv. tabaci (Fig. 6B). In contrast, the water-soaked lesions and disease spread were not readily apparent in two $\mathrm{T}_{1}$ lines (8.1-4b and 7.1-6) of transgenic tobacco containing the DRR206 promoter::FsphDNase construct (Fig. 6B). Subsequently, the $\mathrm{T}_{2}$ lines were screened and tested for resistance against Alternaria alternata. These experiments revealed that some of the transformants decreased the size of the necrotic lesions (Fig. 7) and the radius of the toxin diffusion around these lesions. The DRR206 promoter::FsphDNase construct was also stably transferred to Russet Burbank potatoes (data not shown). Of the 20 transformation lines, lines 16A and 34B were the most resistant against Phytophthora infestans strain US\#8. These and several other lines were subsequently propa-

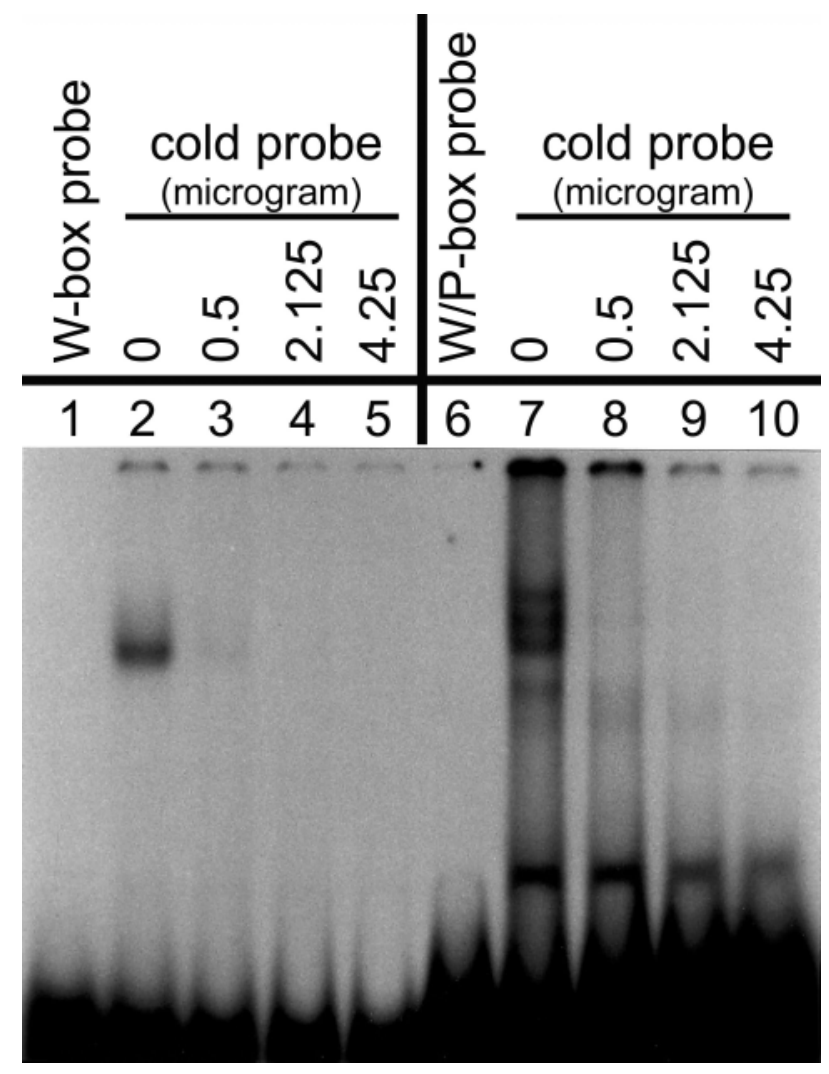

Fig. 4. Electrophoretic mobility shift assay of pea seedling nuclear protein with ${ }^{32} \mathrm{P}$-labeled oligonucleotides containing a single copy of either the WRKY box (W-box) or the wound/pathogen-inducible box (W/P-box). Ten micrograms of the protein was incubated with W-box probe (lanes 2 to 5) or W/Pbox probe (lanes 7 to 10) along with competitor poly[dA/dT] oligonucleotides (1 $\mu \mathrm{g}$ each lane). Competition with unlabeled cold probe was performed at the indicated concentrations in micrograms. Lanes 1 and 6 contain labeled probe without additional proteins. gated by cuttings, and tubers were repeatedly tested for resistance against $P$. infestans and $C$. coccodes. Northern analysis of the expression of FsphDNase in two of these potato lines (7.1-16A and 7.1-34B) indicated that the expression of FsphDNase was similar between the two lines when inoculated with Phytophthora infestans and chitosan treatment (Fig. 8). Wounding induced the expression of FsphDNase at a higher level in potato line 16A than in potato line 34B (Fig. 8). The inoculated potato tissue appeared sensitive to the enhanced presence of FsphDNase product, and the resistance to Phytophthora infestans generated in the engineered plants requires further promoter modification. Most of the nonchallenged transformants showed no detectable morphological differences from the wild type when stably transformed with the DRR206::FsphDNase construct.

These same transgenic lines were also challenged with $C$. coccodes either in the intercellular spaces of the leaf or as a soil inoculum. C. coccodes is known to produce copious units of DNase activity on its own (52). As a consequence, the leaf infusions rapidly formed lesions that restricted further lateral growth that was bordered by regions of dead chlorotic cells. The chlorosis continued in the transgenic tissue to engulf most of the leaf, making this transgenic construct of doubtful use for resistance to C. coccodes in potato. Similarly, the potatoes grown in $C$. coccodes-inoculated soil also developed symptoms comparable to the controls, except that the control plants remained smaller.

\section{DISCUSSION}

A major objective of this study was to identify segments of the pea DRR206 promoter that may be responsive to various stimuli, including plant pathogens or elicitors released from pathogens. Such an inducible promoter may ultimately prove to be an in-

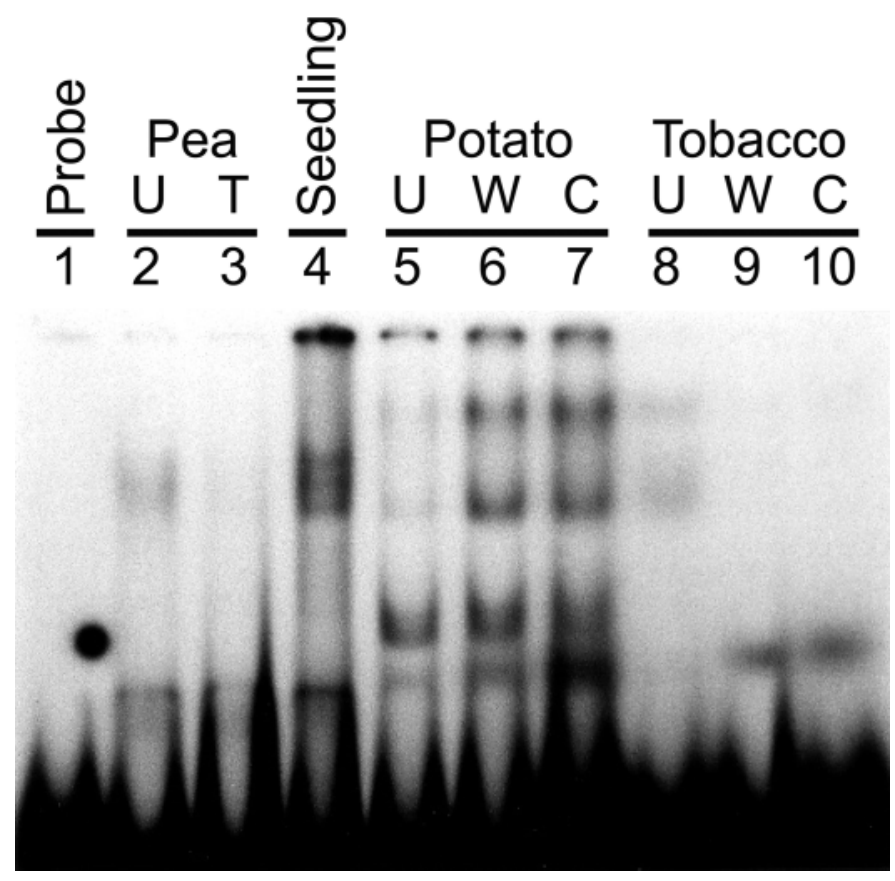

Fig. 5. Electrophoretic mobility shift assay comparing binding affinities of nuclear proteins from pea, tobacco, and potato to a ${ }^{32} \mathrm{P}$-labeled wound/pathogen-inducible box (W/P-box) oligonucleotide derived from the pea DRR206 promoter. Nuclear proteins were derived from untreated (U) pea pods or pea pods treated (T) with Fusarium solani f. sp. phaseoli for $6 \mathrm{~h}$ (lanes 2 and 3); pea seedlings (lane 4); potato leaves untreated (U), wounded (W), or treated with chitosan (C) at $1 \mathrm{mg} \mathrm{ml}^{-1}$ (lanes 5 to 7 ); and tobacco leaves untreated (U), wounded (W), or treated with chitosan (C) at $1 \mathrm{mg} \mathrm{ml}^{-1}$ (lanes 8 to 10). Lane 1 contains the ${ }^{32} \mathrm{P}$-labeled W/P-box probe only. The binding reaction loaded on lane 4 contained $1 \mu \mathrm{g}$ of poly[dA/dT] oligonucleotides and lanes 8 to 10 contained $0.5 \mu \mathrm{g}$ of poly[dA/dT] oligonucleotides due to higher affinity of nonspecific binding. 
valuable tool in developing disease resistance in other plants. Figure 2 indicates that full activity of the DRR206 promoter is dependent on regions of the promoter spanning from 2.7 to $2.3 \mathrm{~kb}$ and 1.9 to $1.4 \mathrm{~kb}$. The pea DRR206 gene, inherently within pea endocarp tissue, is inducible from essentially an inactive state in nontreated tissue, to a low level by wounding, and to a highly active state when induced by fungal challenge, fungal elicitors, and abiotic elicitors (5). Wound inducibility of the DRR206 promoter has a positive role in engineering resistance. Wounding of plant tissues provides a means of entry for pathogens into the plant. Therefore, the DRR206 promoter in combination with the appropriate elicitor should provide additional protection prior to the challenge presented by the pathogen. The DRR206 promoter was further investigated to understand features of the promoter that are associated with up-regulation or down-regulation so that the appropriate promoter segments could be utilized to trigger a broad nonhost resistance response when fused upstream of a gene encoding the FsphDNase elicitor.

Additional characterization of the DRR206 promoter revealed that the 2.7- and 1.9-kb segments of the pea DRR206 promoter were significantly activated across three different plant species using the transient transformation method of agroinfiltration, a technique for nonstable transformation of plant cells. Agroinfiltration bypasses positional effects of gene expression that arise when the transgene is incorporated into regions of the chromatin that are not actively transcribed or are subject to regional influences $(26,41)$. Yang et al. (54) demonstrated the powerful use of agroinfiltration in tobacco leaves by identifying the cis-regulatory regions of promoters that are responsive to salicylic acid signaling. But, agroinfiltration can confound evaluations of elicitor treatments because the transfer relies on the presence of substantial amounts of bacterial cells, which possess elicitors of their own. Thus, the process of agroinfiltration, and the wounding that accompanies this process, activates the DRR206 promoter and the activity is maintained for many days following infiltration. Consequently, agroinfiltration was confined to analyzing potential response elements of the DRR206 promoter.

Transient transformation also required optimization for each plant species. Agroinfiltration of tobacco resulted in optimal GUS activity throughout $6 \mathrm{dpi}$, yet the optimal activity was observed at 3 dpi for potato and 5 dpi for pea. Reproducibility of the agroinfiltration experiments was dependent on the use of optimal tissue under uniform conditions, as observed by Yang et al. (54), who also found that consistent GUS activity requires the use of leaves that are not yet fully expanded. Also, Agrobacterium tumefaciens requires a wound-released phenolic signal molecule from the plant to trigger the vir genes necessary for T-DNA transfer. Hence, supplementation of acetosyringone as a signal is an integral part of agroinfiltration.

Analysis of GUS reporter activity in the various plants revealed that the DRR206 gene promoter was not similarly responsive between different plant species, even within the same family (i.e., Solanaceae). Different patterns of protein-DNA complexes observed with different plant nuclear extracts in the electrophoretic
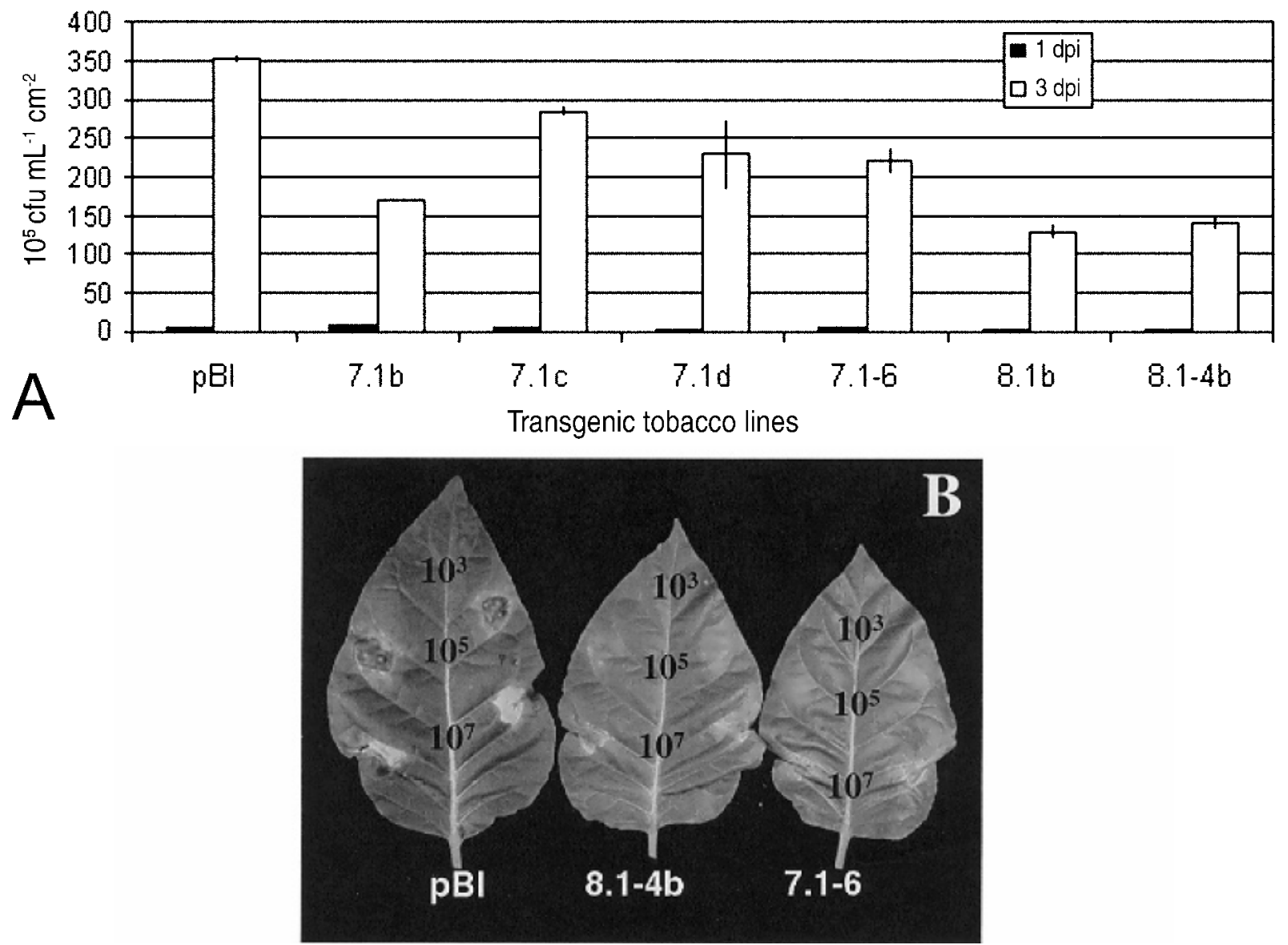

Fig. 6. Resistance of $T_{2}$ transgenic tobacco lines stably transformed with a DRR206 promoter::FsphDNase construct. A, Leaves of four tobacco plants from each transgenic line were inoculated with approximately $100 \mu \mathrm{l}$ of a bacterial suspension of Pseudomonas syringae pv. tabaci $\left(10^{5} \mathrm{CFU} \mathrm{ml}{ }^{-1}\right)$. Two areas were inoculated on each leaf for a total of eight areas on each tobacco plant line. Leaf disks were harvested at 1 or 3 days postinfiltration (dpi), combined (eight disks), and ground in a mortar and pestle with phosphate buffer and plated in replicate for counting. Tobacco lines included pBI (35S::GUS), 7.1 (2.7-kb DRR206 promoter::FsphDNase), and 8.1 (1.9-kb DRR206 promoter::FsphDNase). Letter designations (b to d) represent plants within each transformation event. Error bars indicate standard deviation from the mean. B, Pathogenicity symptoms of tobacco $\mathrm{T}_{1}$ lines 8.1-4b and 7.1-6 transformed with constructs of 1.9-kb DRR206 promoter::FsphDNase and 2.7-kb DRR206 promoter::FsphDNase, respectively. The pBI line contains 35S::GUS. The symptoms were observed at 7 dpi following inoculation of the leaves with $2 \times 10^{3}, 2 \times 10^{5}$, and $2 \times 10^{7} \mathrm{CFU} \mathrm{m}{ }^{-1}$ of Pseudomonas syringae pv. tabaci. 
mobility shift assays with the W/P-box may be indicative of this result. That is, various components of the transcriptional machinery that drive PR gene expression are likely to be different between plant genera (39). Electrophoretic mobility shift assays with the W/P-box and nuclear extracts revealed binding by multiple factors in pea, potato, and tobacco. In contrast, only a single complex was observed between pea nuclear extracts from seedlings and the W-box. Mobility shift assays with the W/P-box probe resulted in similar-sized protein-DNA complexes in potato, tobacco, and pea, with potato possessing an additional complex. Pea nuclear extract from the seedling stage had an $\approx 50$-fold affinity for the pea-based probe relative to tobacco, potato, and even pea pod nuclear proteins binding to the same region. Thus, the W/P-box may be an important element recognized during development, recruiting factors in developing seedlings. Additionally, similar to the observations of Van der Hoorn et al. (50), only a moderate level of GUS expression associated with agroinfiltration was observed in Pisum sativum in comparison to the level observed in solanaceous plants. One plausible explanation is that pea plants have smaller leaves with less intercellular space accessible to bacteria. Furthermore, potato, a solanaceous plant, had diminished reporter gene activity when compared with $N$. tabacum cv. Xanthi, another solanaceous plant.

Eukaryotic gene regulation involves the concerted efforts of both cis- and trans-acting elements. The DRR206 promoter contains one site that bears identity with a W-box binding site for WRKY transcription factors $(13,14)$. These factors, having the conserved WRKYGQK amino acid motif, are unique to plants and are defined by their ability to recognize and bind to $\mathrm{W}$-boxes (T)TGAC(C), TGAC-Nx-GTCA (42). Several recent studies have underscored the importance of the W-boxes in host-pathogen interactions $(13,55)$. For example, the St-WRKY1 gene encoding a WRKY-like transcription factor, is induced when potato is challenged with Erwinia carotovora subsp. atroseptica (11). The Wbox also occurs in many defense gene promoters including the class I basic chitinase promoter of potato and tobacco $(2,17)$. Promoter deletion analyses in this study indicated that the single W-box in the pea DRR206 promoter did not significantly affect the activation of the reporter gene. Maleck et al. (33) screened a DNA microarray with 10,000 Arabidopsis expressed sequence tags (representing 25 to $30 \%$ of the genome) with different pathogens. Of the induced genes, the promoters from 25 genes contained an average of four copies of the W-box (TTGAC) clustered within a kilobase. Promoters of genes not coordinately regulated with PR-1 had less than two copies of the W-box. Since the pea DRR206 promoter contains only one W-box, the relevance of this site in DRR206 defense gene induction may be brought into question. Lebel et al. (31) used linker-scanning constructs to demonstrate that the W-box (TTGACC) and the PR-box (GCCGCC) of the Arabidopsis PR-1 gene were not necessary for PR-1 induction. Instead, the TCA-element (ACGTCA) and the NF- $\mathrm{B}$ (GGACTTTTC) binding site were essential for induction. However, the results of the mobility shift assays in this study with the W/P-box indicate that this element is bound by response-related trans-acting factors, particularly in pea and tobacco. The E-box/ nematode-responsive element, CANNTG, present in multiple copies within the functional sequence of the pea DRR206 promoter, is an evolutionarily conserved recognition site for nuclear factors (47) and may contribute to inducibility (37).

Some yeast and plant promoters, including the pea DRR206 promoter (Fig. 3), contain long stretches of AT-rich DNA, which typically have been associated with the positive regulation of transcription $(4,43,48,49)$. Similarly, long stretches of AT-rich DNA sequence in the pea DRR206 promoter were previously implicated in gene activation. Photoactivated psoralens, which preferentially bind AT-rich DNA sequences, proximal to gene DRR206 induce its expression in pea tissue (35). Alternately, these sequences appear to be associated with the HMG-I/Y family of transcription factors that bind to AT-rich duplex DNA (24) and alter the structure as well as the thermal stability of the region (38). Recently, a pathogen-elicited suppression in the transcription and subsequent synthesis of the pea HMG-I/Y protein has been associated with an enhanced expression of PR genes (29). The purified pea HMG-I/Y protein efficiently binds to the AT-rich sequences of the DRR206 promoter (referred to in Fig. 3). Plant

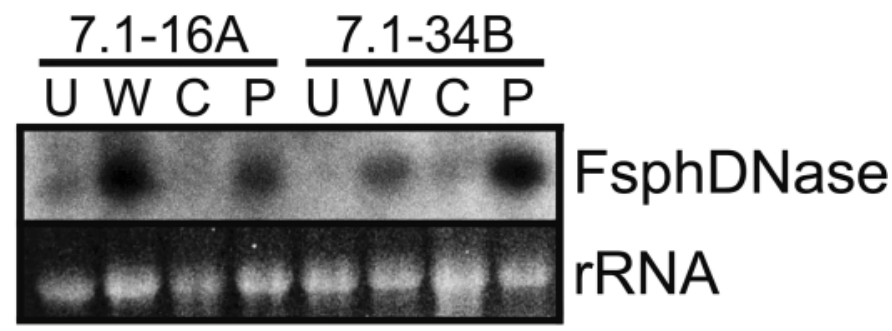

Fig. 8. Northern analysis of FsphDNase expression in two resistant potato lines (7.1-16A and 7.1-34B) transgenic with the 2.7-kb DRR206 promoter: FsphDNase construct. Potato leaves were untreated (U), wounded (W), treated with $10 \mathrm{mg}$ of chitosan (C) ml-1, or inoculated with $1 \times 10^{4}$ spores $\mathrm{ml}^{-1}$ of Phytophthora infestans (P). The blot was probed with a 513-bp ${ }^{32} \mathrm{P}-$-labeled FsphDNase cDNA. Ethidium bromide staining of rRNA is shown.

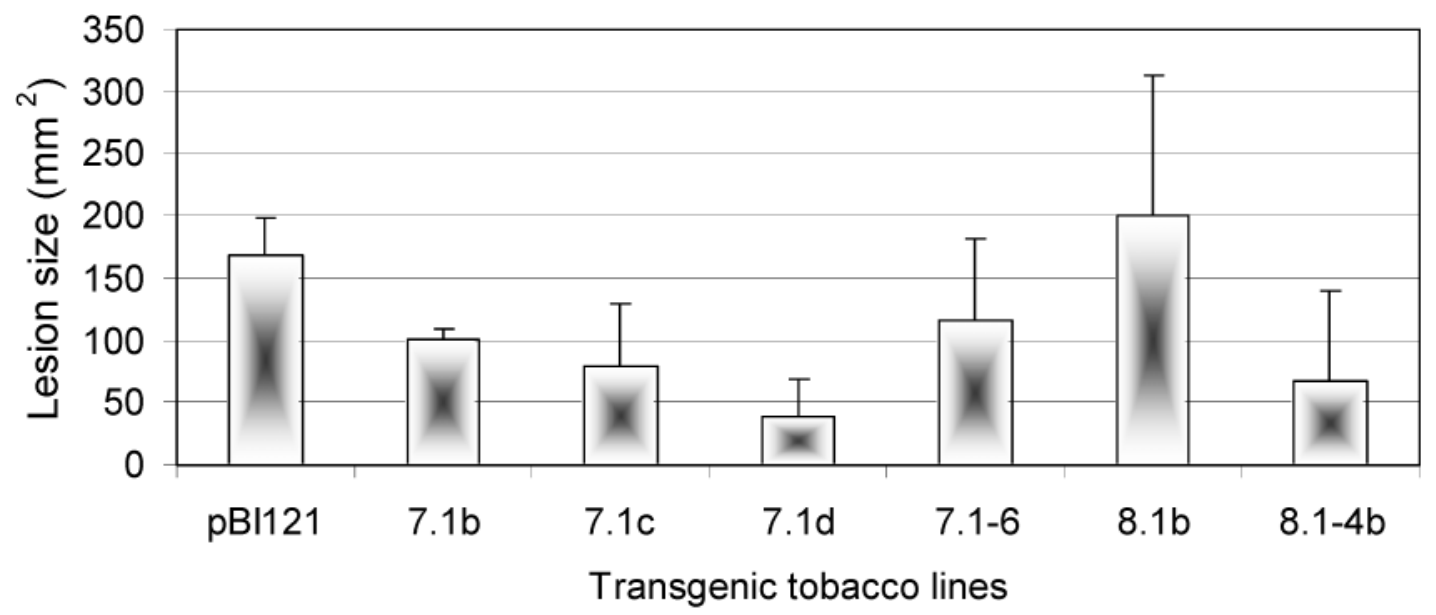

Fig. 7. The relative resistance of tobacco containing the DRR206::FsphDNase gene construct. Immature leaves were inoculated with $50 \mu \mathrm{l}$ of $1.2 \times 10^{5}$ spores $\mathrm{ml}^{-1}$ of Alternaria alternata and incubated at $22^{\circ} \mathrm{C}$ for 7 days. Designations: pBI121 $=35 \mathrm{~S}::$ Gus; $7.1=2.7-\mathrm{kb}$ DRR206 promoter::FsphDNase; 8.1-4b $=1.9-\mathrm{kb}$ DRR206 promoter::FsphDNase. Lesion size $\left(\mathrm{mm}^{2}\right)$ was taken as the average of a total of six plants per plant line, with two areas inoculated per leaf. Error bars indicate the standard deviation from the mean. 
HMG-I/Y proteins have been implicated in the regulation of developmental, defense-related, and light-regulated gene expression (30).

Stable transfer of the chimeric gene fusion of the DRR206 promoter::FsphDNase elicitor to tobacco resulted in significant fungal and bacterial resistance, although the resistance observed was not complete immunity. When challenged with Pseudomonas syringae pv. tabaci, there was a significant decrease in colony forming units in the transgenic tobacco lines 8.1-4b (P2061.9kb::FsphDNase) and 7.1-6 (P206-2.7kb::FsphDNase) lines. Likewise, these same lines, challenged with a fungal pathogen Alternaria alternata, decreased lesion size and diminished spread of toxin. Thus, when fused with the FsphDNase gene and driving its expression, these two segments are effective in triggering a nonhost resistance response. The FsphDNase elicitor is presumed to act by causing single-strand nicks in host DNA although FsphDNase may be recognized by cellular factors, which in turn activate defense gene expression (28). Increasing evidence indicates the existence of different pathways for wound/ pathogen-induced signaling in different plant species. In spite of the differences, it appears there may be some similarities in signaling for wounding, nonhost resistance, and specific R genemediated resistance since each of these can induce PR gene expression.

In summary, these findings provide insight into the regulatory regions of the pea DRR206 promoter and demonstrate the suitability of this promoter, in combination with a gene coding a PR gene eliciting nonhost resistance in plants. Results of this study indicate that the FsphDNase elicitor was capable of inducing resistance, heterologously, in tobacco. However, the pathological assays of transgenic potato containing the DRR206::FsphDNase construct appeared to be sensitive to the probable increases in FsphDNase and did not exhibit useful resistance to $P$. infestans or C. coccodes. Because of this sensitivity, a less responsive promoter or a down graded DRR206 promoter construct may prove to be more suitable. DRR206 promoter sequences were identified that may subsequently assist in the purification of certain transacting factors associated with the promoter elements. For example, the sequence from the W/P-box can now be utilized in affinity purification of putative trans-acting factors.

\section{ACKNOWLEDGMENTS}

We thank J. Chen for technical assistance with the agroinfiltration constructs, D. Johnson for Phytophthora infestans (US\#8) inoculum, T. Peever for the Alternaria alternata culture, B. Schroeder for rifampicin-resistant Pseudomonas syringae pv. tabaci, P. Shiel for sterile Russet Burbank potatoes, Z. Atallah for statistical analysis using SAS, and the University of Washington Sea Grant Program (RB/38) for support. Washington State College of Agriculture and Home Economics Paper 0340.

\section{LITERATURE CITED}

1. Baker, D. L., Dave, V., Reed, T., Misra, S., and Periasamy, M. 1998. A novel $\mathrm{E}$ box/AT-rich element is required for muscle-specific expression of the sarcoplasmic reticulum $\mathrm{Ca}^{2+}$-ATPase (SERCA2) gene. Nucleic Acids Res. 26:1092-1098.

2. Beerhues, L., and Kombrink, E. 1994. Primary structure and expression of mRNAs encoding basic chitinase and 1,3- $\beta$-glucanase in potato. Plant Mol. Biol. 24:353-367.

3. Buttner, M., and Singh, K. B. 1997. Arabidopsis thaliana ethylene-responsive element binding protein (AtEBP), an ethylene-inducible, GCC box DNA-binding protein interacts with an ocs element binding protein. PNAS 94:5961-5966.

4. Chen, W., Tabor, S., and Struhl, K. 1987. Distinguishing between mechanisms of eukaryotic transcriptional activation with bacteriophage T7 RNA polymerase. Cell 50:1047-1055.

5. Choi, J. J., Klosterman, S. J., and Hadwiger, L. A. 2001. A comparison of the effects of DNA-damaging agents and biotic elicitors on the induction of plant defense genes, nuclear distortion, and cell death. Plant Physiol. 125:752-762.
6. Chomczynski, P., and Sacchi, N. 1987. Single-step method of RNA isolation by acid guanidium thiocyanate-phenol-chloroform extraction. Anal. Biochem. 162:156-159.

7. Culley, D. E., Horovitz, D., and Hadwiger, L. A. 1995. Molecular characterization of disease-resistance response gene DRR206-d from Pisum sativum (L.). Plant Physiol. 107:301-302.

8. Daniels, C. H., Fristensky, B., Wagoner, W., and Hadwiger, L. A. 1987. Pea genes associated with non-host disease resistance to Fusarium are also active in race-specific disease resistance to Pseudomonas. Plant Mol. Biol. 8:309-316.

9. Davin, L. B., Wang, H. B., Crowell, A. L., Bedgar, D. L., Martin, D. M., Sarkanen, S., and Lewis, N. G. 1997. Stereoselective bimolecular phenoxy radical coupling by an auxiliary (dirigent) protein without an active center. Science 275:362-366.

10. DeGreve, H., Dhaese, P., Seurinck, J., Lemmer, M., Van Montagu, M., and Schell, J. 1983. Nucleotide sequence and transcript map of the Agrobacterium tumefaciens $\mathrm{Ti}$ plasmid-encoded octopine synthase gene. J. Mol. Appl. Genet. 1:499-511.

11. Dellagi, A., Heilbronn, J., Avrova, A. O., Montesano, M., Palva, E. T., Stewart, H. E., Toth, I. K., Cooke, D. E. L., Lyon, G. D., and Birch, P. R. J. 2000. A potato gene encoding a WRKY-like transcription factor is induced in interactions with Erwinia carotovora subsp. atroseptica and Phytophthora infestans and is coregulated with class I endochitinase expression. Mol. Plant-Microbe Interact. 13:1092-1101.

12. Escobar, E., DeMeutter, J., Aristizabla, F. A., Sanz-Alferez, S., del Campo, F. F., Barthels, N., van der Eycken, W., Seurink, J., Van Montagu, M., Greyse, G., and Fenoll, C. 1999. Isolation of LEMMI9 gene and promoter analysis during a compatible plant-nematode interaction. Mol. Plant-Microbe Interact. 12:440-449.

13. Eulgem, T., Rushton, P. J., Robatzek, S., and Somssich, I. E. 2000. The WRKY superfamily of plant transcription factors. Trends Plant Sci. 5:199-206

14. Eulgem, T., Rushton, P. J., Schmelzer, E., Hahlbrock, K., and Somssich, I. E. 1999. Early nuclear events in plant defence signaling: Rapid gene activation by WRKY transcription factors. EMBO J. 18:4689-4699.

15. Foster, R., Izawa, T., and Chua, N. H. 1994. Plant bZIP proteins gather at ACGT elements. FASEB J. 8:192-200.

16. Fristensky, B., Riggleman, R. C., Wagoner, W., and Hadwiger, L. A. 1985. Gene expression in susceptible and disease resistant interactions of peas induced with Fusarium solani pathogens and chitosan. Physiol. Plant Pathol. 27:15-28.

17. Gang, D. R., Costa, M. A., Fujita, M., Dinkova-Kostova, A. T., Wang, A. T., Burlat, H. B., Martin, V., Sarkanen, S., Davin, L. B., and Lewis, N. G. 1999. Regiochemical control of monolignol radical coupling: A new paradigm for lignin and lignan biosynthesis. Chem. Biol. 6:143-151.

18. Gerhold, D. L., Pettinger, A. J., and Hadwiger, L. A. 1993. Characterization of a plant-stimulated nuclease from Fusarium solani. Physiol. Mol. Plant Pathol. 43:33-46.

19. Goldsbrough, A. P., Albrecht, H., and Stratford, R. 1993. Salicylic acidinducible binding of a tobacco nuclear protein to a $10 \mathrm{bp}$ sequence which is highly conserved among stress-inducible genes. Plant J. 3:563-571.

20. Hadwiger, L. A., Chang, M. M., and Parsons, A. 1995. Fusarium solani DNase is a signal for increasing expression of nonhost disease resistance response genes, hypersensitivity, and pisatin production. Mol. PlantMicrobe Interact. 8:871-879.

21. Hadwiger, L. A., Chiang, C. C., and Horovitz, D. 1992. Expression of disease resistance response genes in near-isogenic pea cultivars following challenge by Fusarium oxysporum race 1. Physiol. Mol. Plant Pathol. 40:259-269.

22. Hadwiger, L. A., and Culley, D. E. 1993. Non-host resistance genes and race-specific resistance. Trends Microbiol. 1:136-141.

23. Honée, G., Melchers, L. S., Vleeshouwers, V. G. A. A., van Roekel, J. S. C., and de Wit, P. J. G. M. 1995. Production of the AVR9 elicitor from the fungal pathogen Cladosporium fulvum in transgenic tobacco and tomato plants. Plant Mol. Biol. 29:909-920.

24. Jacobsen, K., Laursen, N. B., Jensen, E. O., Marcker, A., Poulsen, C., and Marcker, K. A. 1990. HMG I-like proteins from leaf and nodule nuclei interact with different AT motifs in soybean nodulin promoters. Plant Cell 2:85-94.

25. Jensen, E. O., Marcker, K. A., Schell, J., and de Bruijin, F. J. 1988. Interaction of a nodule specific, trans-acting factor with distinct DNA elements in the soybean leghaemoglobin ibc $35^{\prime}$ upstream region. EMBO 7:1265-1271.

26. Kapila, J., De Rycke, R., Van Montagu, M., and Angenon, G. 1997. An Agrobacterium-mediated transient gene expression system for intact leaves. Plant Sci. 122:101-108.

27. Karcher, S. 1995. Molecular Biology: A Project Approach. Academic Press, San Diego.

28. Klosterman, S. J., Chen, J., Choi, J. J., Chinn, E. E., and Hadwiger, L. A. 2001. Characterization of a $20 \mathrm{kDa}$ DNase elicitor from Fusarium solani 
f. sp. phaseoli and its expression at the onset of induced resistance in Pisum sativum. Mol. Plant Pathol. 2:147-158.

29. Klosterman, S. J., Choi, J. J., and Hadwiger, L. A. 2003. Analysis of pea HMG-I/Y expression suggests a role in defence gene regulation. Mol. Plant Pathol. 4:249-258.

30. Klosterman, S. J., and Hadwiger, L. A. 2002. Plant HMG proteins bearing the AT-hook motif. Plant Sci. 162:855-866.

31. Lebel, E., Heifetz, P., Thorne, L., Uknes, S., Ryals, J., and Ward, E. 1998. Functional analysis of regulatory sequences controlling PR-1 gene expression in Arabidopsis. Plant J. 16:223-233.

32. Leon, J., Rojo, E., and Sanchez-Serrano, J. J. 2001. Wound signaling in plants. J. Exp. 52:1-9.

33. Maleck, K., Levine, A., Eulgem, T., Morgan, A., Schmid, J., Lawton, K. A., Dangl, J. L., and Dietrich, R. A. 2000. The transcription of Arabidopsis thaliana during systemic acquired resistance. Nat. Genet. 4:403-410.

34. Palm, C. J., Costa, M. A., An, G., and Ryan, C. A. 1990. Wound-inducible nuclear protein binds DNA fragments that regulate a proteinase inhibitor II gene from potato. Proc. Natl. Acad. Sci. USA 87:603-607.

35. Parsons, M. A., and Hadwiger, L. A. 1998. Photoactivated psoralens elicit defense genes and phytoalexin production in pea plant. Photochem. Photobiol. 67:438-445.

36. Punja, Z. K. 2001. Genetic engineering of plants to enhance resistance to fungal pathogen: A review of progress and future prospects. Can. J. Plant Pathol. 23:216-35.

37. Puzio, P. S., Lausen, J., Heinen, P., and Grundler, F. M. W. 2000. Promoter analysis of pyk20, a gene from Arabidopsis thaliana. Plant Sci. 157:245-255

38. Reeves, R., and Nissen, M. 1990. The AT-DNA-binding domain of mammalian high mobility group I chromosomal proteins. J. Biol. Chem. 265: 8573-8582.

39. Riechmann, J. L., and Meyerowitz, E. M. 1998. The AP2/EREBP family of plant transcription factors. Biol. Chem. 379:633-646.

40. Riggleman, R. C., Fristensky, B., and Hadwiger, L. A. 1985. The disease resistance response in pea is associated with increased levels of specific mRNAs. Plant Mol. Biol. 4:81-86.

41. Rossi, L., Escudero, J., Hohn, B., and Tinland, B. 1993. Efficient and sensitive assay for T-DNA-dependent transient gene expression. Plant Mol. Biol. Rep. 11:220-229.

42. Rushton, P. J., and Somssich, I. E. 1998. Transcriptional control of plant genes responsive to pathogens. Curr. Opin. Plant Biol. 1:311-315.

43. Russell, D. W., Smith, M., Cox, D., Williamson, V. M., and Young, E. T. 1983. DNA sequences of two yeast promoter-up mutants. Nature
304:652-654.

44. Schug, J., and Overton, G. C. 1997. TESS: Transcription Element Search Software. Technical Report CBIL-TR-1997-1001-v0.0. Published online by Computational Biology and Informatics Laboratory, School of Medicine, University of Pennsylvania.

45. Singh, K. B., Zhang, B., Narasimhulu, S. B., and Foley, R. C. 1994 Analysis of Ocs-element enhancer sequences and their binding factors. Pages 197-207 in: Plant Promoters and Transcription Factors, Results and Problems in Cell Differentiation 20. L. Nover, ed. Springer-Verlag, Berlin.

46. Somssich, I. E., and Hahlbrock, K. 1998. Plant defence in plants-A paradigm of biological complexity. Trends Plant Sci. 3:86-90.

47. Staiger, D., Kauren, H., and Schell, J. 1989. A CACGTG motif of the Antirrhinum majus chalcone synthase promoter is recognized by an evolutionary conserved nuclear protein. Proc. Natl. Acad. Sci. USA 6:6930-6934.

48. Struhl, K. 1985. Naturally occurring poly(dA-dT) sequences are upstream promoter elements for constitutive transcription in yeast. Proc. Natl. Acad. Sci. USA 82:8419-8423.

49. Tjaden, G., and Coruzzi, G. M. 1994. A novel AT-rich DNA binding protein that combines an HMG I-like DNA binding domain with a putative transcription domain. Plant Cell 6:107-118.

50. Van der Hoorn, R. A. L., Laurent, F., and Roth, R., and De Wit, P. J. G. M. 2000. Agroinfiltration is a versatile tool that facilitates comparative analyses of Avr9/Cf-9-induced and Avr4/Cf-4-induced necrosis. Mol. Plant-Microbe Interact. 13:439-446.

51. Wang, Y., Nowak, G., Culley, D., Hadwiger, L. A., and Fristensky, B. 1999. Constitutive expression of pea defense gene DRR206 confers resistance to blackleg (Leptosphaeria maculans) disease in transgenic canola (Brassica napus). Mol. Plant-Microbe Interact. 12:410-418.

52. Watkins, W. T., and Hadwiger, L. A. 1998. A nuclease released from Colletotrichum coccodes in not a defence gene elicitor in pea tissue. Mycol. Res. 102:167-173.

53. Wu, H., Michler, C. H., LaRussa, L., and Davis, J. M. 1999. The pine Pschi4 promoter directs wound-induced transcription. Plant Sci. 142:199207.

54. Yang, Y., Li, R., and Qi, M. 2000. In vivo analysis of plant promoters and transcription factors by agroinfiltration of tobacco leaves. Plant J. 22:543551.

55. Yu, D., Chen, C., and Chen, Z. 2001. Evidence for an important role of WRKY DNA binding proteins in the regulation of NPR1 gene expression. Plant Cell 13:1527-1539. 